\title{
Cost-consequence analysis of Pharmaceutical Care program for systemic arterial hypertension in the public health system in Brazil
}

\author{
Maurílio de Souza Cazarim ${ }^{1 *}$, Altacílio Aparecido Nunes², Leonardo Régis Leira Pereira ${ }^{1}$
}

\author{
${ }^{1}$ Department of Pharmaceutical Sciences, School of Pharmaceutical Sciences of Ribeirão Preto, University of São Paulo, \\ Ribeirão Preto, São Paulo, Brazil, ${ }^{2}$ Department of Social Medicine, School of Medicine of Ribeirão Preto, University of São \\ Paulo, Ribeirão Preto, São Paulo, Brazil
}

\begin{abstract}
In Brazil, $80 \%$ of hypertensive patients have no blood pressure controlled, this fact has caused severe financial consequences for the public health system (PHS) and the Pharmaceutical Care (PC) has emerged as an effective alternative. The aim of this study was to analyze the costs and outcomes of systemic arterial hypertension (SAH) for conventional assistance compared to assistance with PC in the PHS. This is a pharmacoeconomic study with cost-consequence analysis nested to clinical trial. Hypertensives patients were followed-up from 2006 to 2012. During 2009 they were assisted by the PC program in Ribeirão Preto-SP, Brazil. Clinical indicators, systolic and diastolic blood pressure (SBP and DBP), triglycerides, total cholesterol (TC) and its fractions and healthcare indicators, consumption of antihypertensive medication and consultations were analyzed. Costs were listed as direct medical and direct non-medical. The average cost of conventional care for 104 patients followed-up was US\$198.97, in the PC period and after discharge was US\$ 407.91 and US\$ 214.96 patient/year. After discharge of patients from PC there was reduction of SBP, DBP, TC and cardiovascular risk, $9.4 \mathrm{mmHg}, 4.6 \mathrm{mmHg}, 12.0 \mathrm{mg} / \mathrm{dL}$, and $23 \%[\mathrm{p}<0.005]$, respectively. The PC program optimized clinical and healthcare indicators and impacted in the SAH costs for the PHS.
\end{abstract}

Keywords: Pharmaceutical economics. Pharmaceutical services. Health Expenditures. Hypertension. Pharmaceutical care. Costs and cost analysis.

\section{INTRODUCTION}

Of a total of 56 million deaths worldwide in 2012, 38 million were due to chronic non-transmittable diseases. Among them, is highlighted the Systemic arterial hypertension (SAH) (WHO, 2003; Brasil, 2008; WHO, 2014a). It has affected, approximately, one third of the population, reaching over $50 \%$ of people in old age and $5 \%$ of children and adolescents (Cipullo et al., 2010; WHO, 2013; WHO, 2014b; Malachias et al., 2016). Blood pressure, if not controlled, is considered an important risk factor for the occurrence of other diseases of the circulatory system i.e. cardiovascular diseases (CVD) (WHO, 2011; WHO, 2013; WHO, 2014b; Malachias et al., 2016). In addition, $20 \%$ of hypertensive patients have blood pressure

\footnotetext{
*Correspondence: M. S. Cazarim. Centro de Pesquisa em Assistência Farmacêutica e Farmácia Clínica (CPAFF), Faculdade de Ciências Farmacêuticas de Ribeirão Preto, Universidade de São Paulo, Sala 23, bloco S, 14040-903 - Av. Café, s/nº, Ribeirão Preto - SP, Brasil. Phone: +55 16 3315-4236. E-mail: maurilio.jf@gmail.com
}

within the recommended range of the VII guideline of the Brazilian Society of Cardiology (BSC), which is considered a low rate (Pontes-Neto et al., 2008; Malachias et al., 2016). There are studies that show a control pressure percentage below $20 \%$ among hypertensive patients in Brazil (Jardim et al., 2007; Rosário et al., 2009).

The consequence of this SAH situation in Brazil was presented by the VII guideline of the BSC (Malachias et al., 2016), which translates to about 1.2 million hospital admissions in Brazil being linked to CVDs. This reality refers to the fact that SAH has an annual cost of about 780 million dollars for health systems, showing that the representative portion for the Public Health System (PHS) amounts to approximately 462 million dollars (Malachias et al., 2016).

The PHS has sought alternatives to work around this panorama of SAH in Brazil, outlining strategies and care proposals that promote improved clinical results and preventive patient care (Araújo, Ueta, Freitas, 2005; Malachias et al., 2016). A health technology capable 
of providing better prospects in the control of chronic diseases, especially SAH, is Pharmaceutical Care (PC) (Araújo, Ueta, Freitas, 2005; De-Castro, Correr, 2007; Lyra-Jr, Marcellini, Pelá, 2008; Pereira, Freitas, 2008; Zubioli et al., 2013). It is a model of professional practice in which the pharmacist uses clinical and humanistic skills to promote patient care through pharmacotherapeutic follow up (Ivama et al., 2002). Some studies have shown that PC is effective not only in controlling blood pressure, but also in reducing health complications caused by SAH (Machado et al., 2007; Aguwa, Ukwe, Ekwunife, 2008; Lyra-Jr, Marcellini, Pelá, 2008). However there is a need to assess the financial impact of PC together with clinical results achieved so this practice is encouraged in the PHS.

Pharmacoeconomics is a science that studies the economic evaluation of health products and services. Among different pharmacoeconomic analyses there is the cost-consequence analysis, which enables to visualize the costs and outcomes for a specific morbidity, thus, generate hypotheses and design scenarios to assist health management. In this context, the aim of this study was to analyze the costs and outcomes of SAH for conventional assistance compared to assistance with PC in the PHS.

\section{SUBJECTS AND METHOD}

\section{Study design and delineation}

This is a pharmacoeconomic study nested to clinical trial with a cost-consequence analysis in perspectives to PHS. From March to November 2014 data were collected for this study. These data are divided into clinical, healthcare, and economic. Clinical and healthcare data refer to the monitoring of hypertensive patients during the years 2006 to 2012 by the Research Centre for Pharmaceutical Care and Clinical Pharmacy (CPAFF), Faculty of Pharmaceutical Sciences of Ribeirão Preto, University of São Paulo (FCFRP-USP). In 2009 there was a PC program developed by the CPAFF, which assisted these patients for twelve months. Thus, the clinical data of the three years preceding the program (2006-2008) represented this study of years without PC, with conventional care, it is proposed in three levels of care in the PHS, basic care; Specialized/emergency care; Tertiary care (hospital admissions and more complex care). All care levels provide multiprofessional care and the patients get free basic medicines to treat hypertension. 2009 was the year with PC, and the three subsequent years (2010-2012) represented the years Post PC. Clinical data were collected through patient medical records and pharmaceutical and healthcare records through the Hygiaweb ${ }^{\circledR}$ computerized system.
This study has approval by the Ethics in Research Committee of the FCFRP/USP, February 10, 2014, with the release of approval No. 004/2014 and protocol CEP/ FCFRP 324, CAAE 21162713.8.0000.5403 and protocol No. 526.507 (http://plataformabrasil.saude.gov.br).

\section{Pharmaceutical Care program implemented for the care of hypertension}

Individuals diagnosed with SAH were included in the PC program, being residents of Ribeirão Preto, SP, aged over 20 years, in medical care for SAH, PHS users and taking antihypertensive medication (AH). Patients who could not continue the planning of PC consultations, pregnant women, nursing mothers, and those who had diagnosed cognitive impairment were excluded. The PC program was developed in two basic health units of the PHS in Ribeirão Preto, a district and another site. One monthly consultation per patient was scheduled, totaling twelve appointments in the year for each patient. They were based on the pharmacotherapeutic monitoring strategies of the North American PWDT (Pharmacist Workup of Drug Therapy) model (Cipolle, Strand, Morley, 1998). A pharmacist of CPAFF was responsible for leading the program and conducting consultations in both health units, which took place on a monthly basis for each patient. In the first consultation the patient's medical history, lifestyle, eating habits, socio-demographic data (gender, age, skin color, education, occupational activity, income) and measures of the profile of cardiovascular risk (obesity, dyslipidemia, family history, smoking, diabetes and waist circumference) were addressed.

Subsequent consultations followed the activities related to the pharmacotherapeutic monitoring, covering measurements of blood pressure and measures of cardiovascular risk, analysis of medications and test results, health education with guidance on patient behavior regarding life habits, adherence to treatment and when necessary, pharmacotherapy interventions. These data were recorded in the pharmaceutical record along with clinical and healthcare data for patient monitoring. This monitoring is recommended in the $\mathrm{V}$ guideline of BSC for the management of hypertensive patients (BSC, 2007).

\section{Clinical and healthcare indicators of study}

The endpoints evaluated in the follow-up of patients were clinical and healthcare data respectively. Clinical indicators relate to measurements of systolic and diastolic blood pressure (SBP and DBP), and the results of triglycerides (TG), total cholesterol (TC) and 
its lipoprotein fractions of low density (LDL) and High Density Lipoprotein (HDL). The healthcare indicators correspond to the annual number of consultations and the annual consumption of antihypertensive medication (AH). Consultations were classified into primary care (consultations with general practitioners and medical family health), emergency care (consultation for hypertensive crisis in emergency care) and specialized care (consultations in cardiology specialty), and $\mathrm{AH}$ medication were considered those supplied by the PHS, belonging to the Municipal Essential Medicine List. The indicators were analyzed by the annual mean values collected in the patients' records, which did not represent an exact number of values for each year. The patient was excluded from the subgroup analysis for the variable if there was no record for that variable in one of the years of analysis.

\section{Costing}

It was used the mixed method for costing, micro and macro-costing with the technique "top-down", except for anti-hypertensive medications, which the costs were collected from municipality purchase record. Costs were raised by the system of the Municipal Health Department of Ribeirão Preto (MHD-RP) and computerized data of the unified table of the PHS (Brasil, 2015a). The year 2013 was used as the basis for calculating due to data collection. However costs have been adjusted for the year 2015. For this the Consumer Price Index (CPI) was considered which is available in the consolidated economic indicators of Brazil's Central Bank (Brasil, 2013). The conversion into US dollars was made using the exchange rates published by the Central Bank of Brazil (Brasil, 2009; Rascati, 2010).

The costs considered in this study were direct non-medical (absenteeism and transportation) and direct medical (consultations, laboratorial tests, $\mathrm{AH}$ medication). The total annual cost was calculated performing the average for each type of cost considering 51 patients, all patients with medical records available, and records in the computerized system during the years of the study (2006-2012). For a total annual cost, the overall of patients followed up by PC, 104 patients, was multiplied the average annual cost per patient related to each variable. The cost per period and costs per patient were obtained by averaging each of the years in the period.

The calculation of absenteeism was performed according to the average salary among those who worked as non-self employed, considering the percentage of them among the 104 patients, to calculate the total cost and the patient in general. The calculation was performed considering the Brazilian labor law to charge 8 hours of work/day, a month of vacation, 20 days of work in the month (excluding weekends and holidays). The average annual salary amount, considering $13^{\text {th }}$ salary was divided by the total hours worked in the year, obtaining the value of hours worked. This value was multiplied by half a working day period i.e. four hours (considered as missing work to attend the consultation) (Brasil, 2006).

For costs related to transportation it was considered that the patient used public transport to travel to and return from the consultations. For the calculation the value of the flat rate charged in the municipality was used. This cost was assigned for those patients self-employed, the elderly not working, and retired, who use public transport and did not pay the public transport fees or for the ticket (Brasil, 2015d).

In relation to the examinations, those tests used for diagnosis of dyslipidemia, recommended the monitoring of SAH by the VII guideline of BSC (Malachias et al., 2016) to be a morbidity associated with risk factor for CVD were considered. Thus, it included the tests of TG, TC and LDL and HDL fractions (Jellinger et al., 2012). The cost was obtained from the unified table of the PHS (Brasil, 2015a). The calculation was performed for each patient by multiplying the total number of annual examinations by the unit cost of the exam.

Consultations were classified in PC consultations (consultations with the pharmacist, used for the cost calculation of PC), as primary care, emergency care and specialized care. Discriminated data of municipal costs for each health Unit in the city by the Finance Division and Operational Cost of MHD-RP, and the number of consultations broken down by sector/specialty of each health facility in the city by the IT, Statistics, Control and Audit department of MHD-RP were obtained.

Primary care was considered in our study as a general service to the patient's health condition in which there are few discrepancies between the average cost of a hypertensive patient with the general average of patients with other diseases. Thus, the total expenditure considered in this study with a basic health unit and family health strategy, and the total consultations in the health units were used. For the calculation, the division between the annual cost and the annual number of consultations of each unit was performed, obtaining the average cost of a consultation in this segment.

As for emergency care and specialized care it was considered that they cannot be generalized in terms of costs for different morbidities. The hypertensive patient has a different cost in each of these segments and these costs consider the logistics of standardized care for the 
public health services (Brasil, 2015b). Therefore, the basal cost of the emergency units and the basal cost of the basic health unit for outpatient care were calculated. This cost refers to expenditures that are common to any type of patient who enters the unit to be attended to.

To calculate the consultation cost of specialized care, the cost of the electrocardiogram (ECG) examination recommended by the BSC (BSC, 2007; Malachias et al., 2016) as a routine evaluation, nursing care, the consultation with the cardiologist (Brasil, 2015b), and medical monitoring were considered, being these four categories obtained from the unified table of the PHS in 2013 (Brasil, 2015b). To make the calculation, these costs were added to the baseline cost of the care unit. The cost of monitoring was utilized according to the VII guideline of the BSC (Malachias et al., 2016). Thus, routine exams (urinalysis, serum potassium, serum creatinine, uric acid and fasting glucose), and color doppler ultrasound, transthoracic echocardiography and aortic arch angiography examinations every two years were considered, as these examinations are recommended for further evaluation of clinical and subclinical lesions in the target organ. It is noteworthy that for the calculation of the cost of the consultations, an ECG in each consultation and examinations of medical monitoring every six consultations was considered, considering the average of three annual consultations with the cardiologist (Brasil, 2015b; Malachias et al., 2016).

To calculate the cost of the emergency care consultation, the cost of medical care, nursing care, the recommended tests of the VII guideline of the BSC (Malachias et al., 2016) such as the ECG, chest X-ray and creatine phosphokinase (CPK), obtained from the unified table of the PHS were considered (Brasil, 2015a; Malachias et al., 2016). These costs were added to the baseline cost of the care unit and the cost of urgent medication (Brasil, 2015b). The cost of medication was calculated by averaging the unit cost of the medication available on the municipal list for hypertensive emergency, being Hydralazine hydrochloride $20 \mathrm{mg} / \mathrm{ml}$, Sodium nitroprusside $25 \mathrm{mg} / \mathrm{ml}$, Furosemide $10 \mathrm{mg} / \mathrm{ml}$, Captopril $25 \mathrm{mg}$, and Clonidine $0.15 \mathrm{mg}$. For intravenous medication administration, the cost of $0.9 \%$ saline solution and nurse's materials were considered, being the cost obtained by the Pharmacy Division of MHD-RP, and also the cost of administering the drug, obtained from the unified table of the PHS (Brasil, 2015a).

Regarding AH medication, the unit cost was acquired from the acquisition report of the Pharmacy Division of MHD-RP. This value was divided by the amount in milligrams corresponding to each drug to obtain the cost/ milligram. For the calculation, the annual consumption in milligrams of each antihypertensive medication per patient was considered. Consumption was multiplied by the value in milligrams for each medication used by the patient to supplement the cost of AH medication per patient year.

\section{Statistic}

The sample design for the monitoring of patients by PC was based on a sample calculation for experimental studies using an estimated population mean for the dependent variable, systemic blood pressure. It was grounded at the formula $n=\left(\frac{Z_{\alpha / 2} \times d p \Delta}{\varepsilon}\right)^{2}$, where $\mathrm{Z}_{\alpha / 2}$ is the normal standard percentile $\alpha=0,05 ; \mathrm{dp} \Delta$ related to standard deviations before and after the intervention; and $\varepsilon$ is the accuracy, a clinically significant difference after the intervention. The value of $30 \mathrm{mmHg}$ for the $\mathrm{dp} \Delta$ was used from literature (Borges, 2008; Lyra-Jr, Marcellini, Pelá, 2008). A clinically satisfactory reduction in systolic blood pressure between 5-10 mm Hg were considered (Aguwa, Ukwe, Ekwunife, 2008; Lyra-Jr, Marcellini, Pelá, 2008). Thus, for an $\varepsilon$ value between $5-10 \mathrm{mmHg}$ the sample number between 33 and 138 was calculated.

The Statistical Package for Social Sciences ${ }^{\circledR}$ (SPSS) version 19.0 software was used to perform the hypothesis test, considering the significance level of 5\%. The statistical inference was based on data from repeated measures due to this study considering the data from the same individuals at different points in time. Thus, the oneway ANOVA test with Bonferroni post-test was performed for comparison between Pre PC, PC, and Post PC data groups in the analysis of the indicators of SBP, DBP, TC, HDL, LDL, TG and consumption of AH medication, which represent continuous quantitative variables and followed a parametric data distribution. The purpose was to test the hypothesis that there is variation in the average of these indicators, being associated with PC. Regarding the indicator for consultations, which represented a variable of discrete quantitative type and followed a distribution of non-parametric data, the analysis of Friedman variance was performed with Dunn's post-test to compare Pre PC, PC, and Post PC data groups. This analysis was aimed to test the hypothesis that there is variation in the number of consultations being associated with PC. The Framingham risk was calculated for each patient to measure cardiovascular risk in ten years. Thus, one-way ANOVA for repeated measures with the Bonferroni post-test was conducted to verify the change in coronary risk among the years for testing the hypothesis that the PC is able to interfere in coronary risk (Pagano, Gauvreau, 2012). 


\section{RESULTS}

104 patients of the 191 patients selected by consecutive sampling were followed up by the PC program. Thus, the results of this study refer to a population whose sample is represented by the demographic profile of $75.0 \%$ of female patients, $64.4 \%$ above 60 years of age, $55.8 \%$ white skin color, $72.1 \%$ with complete primary education, $68.3 \%$ in occupational activity and $83.7 \%$ with an average family income of one to five times the minimum wage. Regarding the clinical profile, $53.9 \%$ were considered obese (body mass index above $30 \mathrm{~kg} / \mathrm{m}^{2}$ ), $19.2 \%$ with a waist circumference above the reference values $(102 \mathrm{~cm}$ for men and $88 \mathrm{~cm}$ for women) (BSC, 2010), 26.9\% had dyslipidemia, $18.3 \%$ were diabetics, $13.5 \%$ had a family history of SAH and $4.8 \%$ were smokers. In the pre-PC period the average coronary risk was increasing every year $(n=36)$, achieving in the last year $14.3 \% \pm 10.6$. In the $\mathrm{PC}$ period this trend was interrupted, presenting $10.6 \%$ $\pm 7.7[\mathrm{p}<0,001]$ and, the post-PC period was $10.9 \% \pm 7.9$ $[p<0,001]$. Obtained earlier in the monitoring of patients by the PC program, this hypertensive patients profile refer to sample of this study, which has the care and clinical indicators shown in Table I and the cost variables in Table II.

The cost of PC was recorded separately from the cost of treatment offered by the PHS and can be attributed to 2009 , during which there was investment in the PC program for the 104 hypertensive patients (Chart 1).

TABLE I - Analysis of clinical and healthcare indicators by period

\begin{tabular}{|c|c|c|c|c|c|c|c|c|}
\hline \multirow{2}{*}{ Indicators } & \multicolumn{3}{|c|}{ Pre-PC } & \multicolumn{2}{|c|}{ PC } & \multicolumn{2}{|c|}{ Post-PC } & \multirow{2}{*}{$p$ value } \\
\hline & $n$ & Average \pm SD & CI 95\% & Average \pm SD & CI 95\% & Average \pm SD & CI 95\% & \\
\hline \multicolumn{9}{|l|}{ Clinical } \\
\hline DBP (mmHg) & 57 & $83.8 \pm 8.8$ & $(81.4-86.0)^{* *}$ & $75.1 \pm 5.5$ & $(73.7-76.6)$ & $79.2 \pm 7.8$ & $(77.1-81.3)$ & $p<0.001$ \\
\hline $\mathrm{LDL}(\mathrm{mg} / \mathrm{dL})$ & 20 & $136.4 \pm 23.4$ & $(125.4-147.3)$ & $128.5 \pm 37.0$ & $(111.2-145.8)$ & $125.3 \pm 34.9$ & $(109.0-141.6)$ & $p=0.210$ \\
\hline HDL (mg/dL) & 29 & $45.2 \pm 8.3$ & $(42.0-48.4)$ & $45.3 \pm 9.4$ & $(41.7-48.9)$ & $43.2 \pm 7.6$ & $(40.2-46.1)$ & $p=0.105$ \\
\hline \multicolumn{9}{|l|}{ Healthcare } \\
\hline Specialzed care & & $0.60 \pm 0.93$ & $(0.40-0.80)$ & $0.54 \pm 0.86$ & $(0.36-0.72)$ & $0.48 \pm 0.86$ & $(0.30-0.66)$ & $p=0.238$ \\
\hline Emergency care & & $1.70 \pm 1.37$ & $(1.42-2.00)^{* *}$ & $1.17 \pm 1.29$ & $(0.90-1.44)$ & $1.06 \pm 0.81$ & $(0.89-1.23)$ & $p=0.002$ \\
\hline $\begin{array}{l}\text { Anti-hypetensive } \\
\text { medications } \\
\text { (mg per day) } \\
\text { adjusted }\end{array}$ & 82 & $33.95 \pm 20.8$ & $(29.37-38.53)$ & $36.68 \pm 27.8$ & $(30.56-42.79)$ & $35.7 \pm 24.4$ & $(30.34-41.07)$ & $p=0.507$ \\
\hline \multicolumn{9}{|c|}{$\begin{array}{l}\mathrm{PC}=\text { Pharmaceutical Care; } \mathrm{SD}=\text { Standard derivation; } \mathrm{CI}=\text { Confidence Interval for } 95 \% \text {; } \mathrm{SBP}=\text { systolic blood pressure; } \mathrm{DBP}=\text { diastolic blood } \\
\text { pressure; } \mathrm{TG}=\text { triglycerides; } \mathrm{TC}=\text { total cholesterol; } \mathrm{LDL}=\text { Low Density Lipoprotein; } \mathrm{HDL}=\text { High Density Lipoprotein. The sample number was } \\
\text { stratified for each variable to perform the analysis and in conjunction the grouping of the years was performed by period so that the absence of } \\
\text { records does not interfere with the analysis of some variables. The biggest difference } n \text { in healthcare variables compared to clinical variables can } \\
\text { be explained by the online record in the Hygiaweb } \AA \text { system, which would avoid the absence of a record. One-way ANOVA test with Bonferroni } \\
\text { post-test was performed for DBP, TC, HDL, LDL, TG and consumption of AH medication and Friedman variance was performed with Dunn's } \\
\text { post-test to compare the consultations, considering the significance level of } 5 \%, \mathrm{p}<0.005{ }^{*} \text { Evidence of association with PC in comparison with } \\
\text { the Pre-PC and Post-PC period; ** Evidence of association with the PC in the comparisons of the Pre-PC period with PC and Pre-PC with Post- } \\
\text { PC. To compare the use of antihypertensive medication, the daily dose consumed was adjusted by the therapeutic doses comparison model (TDC } \\
\text { model) by Cazarim and Pereira, published by the PLOS ONE (Cazarim et al., 2016). }\end{array}$} \\
\hline
\end{tabular}


TABLE II - Direct costs of hypertensive patients' treatment per year and per period for the cost-consequence analysis

\begin{tabular}{|c|c|c|c|c|c|c|c|}
\hline \multirow{2}{*}{ COST US\$ } & 2006 & 2007 & 2008 & 2009 & 2010 & 2011 & 2012 \\
\hline & & Pre-PC & & PC & \multicolumn{3}{|c|}{ Post-PC } \\
\hline \multirow{2}{*}{\multicolumn{8}{|c|}{$\begin{array}{c}\text { DIRECT } \\
\text { MEDICAL COSTS }\end{array}$}} \\
\hline & & & & & & & \\
\hline Laboratory tests & 349.88 & 442.81 & 390.88 & 513.88 & 582.22 & 483.81 & 437.35 \\
\hline Mean & & 394.52 & & 513.88 & & 501.13 & \\
\hline \multicolumn{8}{|l|}{ Consultation } \\
\hline Primary care & $8,850.23$ & $7,283.00$ & $7,743.95$ & $9,218.99$ & $9,864.32$ & $12,261.26$ & $12,906.59$ \\
\hline Specialized care & $2,688.70$ & $2,688.70$ & $2,491.97$ & $2,557.54$ & $1,901.76$ & $2,688.70$ & $2,098.50$ \\
\hline Emergency care & $4,375.44$ & $5,017.17$ & $7,175.72$ & $4,258.76$ & $5,017.17$ & $3,325.33$ & $2,275.23$ \\
\hline Mean (Primary care) & & $7,959.06$ & & $9,218.99$ & & $11,677.39$ & \\
\hline Mean (Specialized care) & & $2,623.12$ & & $2,557.54$ & & $2,229.66$ & \\
\hline Mean (Emergengy care) & & $5,522.78$ & & $4,258.76$ & & $3,539.25$ & \\
\hline $\begin{array}{l}\text { Anti-hypertensive } \\
\text { medications }\end{array}$ & $1,289.34$ & $1,512,72$ & $1.513,58$ & $1.732,75$ & $1.453,59$ & $1.517,97$ & $1.542,48$ \\
\hline Mean & & $1,438.55$ & & $1,732.74$ & & $1,504.68$ & \\
\hline \multirow{2}{*}{\multicolumn{8}{|c|}{$\frac{\text { DIRECT NON- }}{\text { MEDICAL COSTS }}$}} \\
\hline & & & & & & & \\
\hline Transportation & 96.84 & 146.82 & 171.81 & 118.71 & 128.08 & 134.33 & 103.09 \\
\hline Mean & & 138.49 & & 118.71 & & 121.83 & \\
\hline Absenteeism & $1,994.30$ & $2,414.15$ & $3,253.86$ & $2,099.26$ & $2,729.04$ & $2,938.97$ & $2,676.56$ \\
\hline Mean & & $2,554.11$ & & $2,099.26$ & & $2,781.52$ & \\
\hline $\begin{array}{l}\text { COST PER } \\
\text { PERIOD }\end{array}$ & & $20,630.63$ & & $20,499.89$ & & $22,355.45$ & \\
\hline COST PER & $188.90 \pm 122.60$ & $187.60 \pm 118.00$ & $218.70 \pm 141.10$ & $197.11 \pm 130.20$ & $208.40 \pm 134.60$ & $224.50 \pm 145.30$ & $211.90 \pm 139.30$ \\
\hline PATIENT & & $198.37 \pm 127.23$ & & $197.11 \pm 130.20$ & & $214.96 \pm 139.73$ & \\
\hline
\end{tabular}

$\mathrm{PC}=$ Pharmaceutical Care; bold number $=$ average among the years; cost per patient $=$ average \pm standard deviation; Overall and cost per patient is an average among the years for each period; Laboratory tests include HDL, LDL, CT and TG. Non-medical costs are those related to health care and are not directly related to patient health. Among them were considered absenteeism, missing work due to consultations, and public transportation to go to and return from the consultation. Medical costs, those strictly related to the health of the patient, were listed as the cost of laboratory tests, consultations and AH medication. The total expenses related to health facilities refer to categorized office costs, cleaning, nursing, diverse, permanent, wages, contracted salary (IPMF 22\%, Sassom 5\%, INSS + insurance, FGTS, transportation costs, food stamps), water, energy, telephone, services, contractors, rentals, travel, small incidental expenses taxed as cash, fuel and expenses for the Support Foundation of Teaching, Research and Service of the Clinical Hospital of the Ribeirão Preto Medical School, University of São Paulo. Excluded were dental costs, $x$-ray, and medication, the latter being a cost variable analyzed separately. For the basal cost of the emergency units and the basic health considered were: office costs, cleaning, diverse, permanent, energy, telephone, services, contractors, rentals, travel, cash payments and fuel. For the calculation, the division between the annual cost and the annual number of consultations of each unit was performed, obtaining the average of the basic health unit as the baseline cost of a specialized service and the average of the emergency units as the baseline cost of an urgent or emergency consultation. The conversion into US dollars was made using the exchange rates published by the Central Bank of Brazil, USD \$1.00 equivalent to $\mathrm{R} \$ 3.34$ in the 2015 consolidation.

\section{DISCUSSION}

The prevalence of SAH in individuals over 30 years of age in Ribeirão Preto is estimated at $59 \%$, according to data from the MHD-RP in 2015 (Dib, Riera, Ferraz,
2010). In 2013 the municipality invested in health a total of $26.16 \%$ of the US $\$ 502,530,097.57$ of collected revenues in the same year. This represented the average health care cost of US\$271.99/inhabitant/year for a population of 649,000 inhabitants of the municipality (IBGE, 2013; 
CHART 1 - Description for calculating the cost of pharmaceutical care

\begin{tabular}{|lccc|}
\hline Salary Description US\$ & Taxes & Amount & Annual (with 13 $^{\text {th }}$ salary) \\
\hline Base salary (Sao Paulo) 40 h & & 893.62 & $11,617.02$ \\
G.E.A. - Article 1 LC 391/94 & 0.25 & 223.40 & $2,904.26$ \\
Hazardous Activity 20\% & 0.01675 & 14.97 & 194.59 \\
Additional Incentive Award & 0.0835 & 74.62 & 970.02 \\
Attendance criterion - LC & 0.03 & 26.81 & 348.51 \\
406/94 & & & \\
\hline Total & & US\$ 1,233.41 & US\$ 16,034.39 \\
\hline PC COST DESCRIPTION & & & $16,034.39$ \\
Annual salary & & & 835.34 \\
Materials & & & $5,053.07$ \\
Consultation Room & & US\$ 21,922.81 \\
Total & & & US\$ 210.80 \\
Per patient & & US\$ 17.57 \\
Per consultation & & & \\
\hline
\end{tabular}

The materials considered were for hypertension clinical care (scale, tape measure, unit for measuring blood pressure), furniture (desk, chair, closet), general materials (computer and printer), and office supplies (clipboards, pens, plain paper, record folders, stapler, hole punch, staples, paper clips, trash basket, ruler, highlighter pen). The salary description is according to what is performed in the municipality. The base salary was obtained by the value set by the Regional Pharmacy Council as minimum wage for Pharmacists for the state of São Paulo in 2013. The conversion into US dollars was made using the exchange rates published by the Central Bank of Brazil, USD \$1.00 equivalent to R 3.34 in the 2015 consolidation.

Brasil, 2015b; Brasil, 2015c; Brasil, 2015e). The cost committed annually for the treatment of hypertensive patients in São Paulo, adjusted for the year 2016 was US\$174.24, which represents $64.06 \%$ of US\$ 271.99 per capita spending on health/year in Ribeirão Preto (PontesNeto et al., 2008; Dib, Riera, Ferraz, 2010; Brasil, 2015f). Considering this estimate of prevalence of HAS in the local population over 29 years old, 205,546 habitants, and the cost of the hypertensive patient to the state it is possible to measure an expense of US\$ $35,814,317.61$ annually with hypertension in the municipality, without incorporating in these expenditures comorbidities occurring by complications of disease. This value referred to the $19.91 \%$ of spending on municipal health, which was US\$179,887,997.61 considering the total federal, state and municipal resources applied in 2013. Using as a base the amount committed only by the municipal level US\$ $131,510,354.10$, this percentage rose to $27.23 \%$ of health expenditures (IBGE, 2013; Brasil, 2015b; Brasil, 2015c; Brasil, 2015f).

This study considers the pre-PC period as the baseline for the analysis of the results. Thus, this period refers to the years that conventional treatment was offered by the health system to hypertensive patients of the study. During this period the annual cost per patient diagnosed with SAH was US\$ 198.97 for the municipality, US\$28.73 more than the average committed in the state of São Paulo. This value projects to a cost of US $\$ 40,897,467.72$ for the hypertensive population of the municipality, $31.10 \%$ of spending on municipal health. However, the results of our study showed that the PC was able to change this scenario, increasing the costs after discharge.

Meantime, it is possible to relate this increase of costs to promoting the most appropriate health care to the hypertensive patient because there was evidence for an association with a reduction in hypertensive crises due to improvement in blood pressure achieved by PC and promoting preventive care. As in the case of chronic nontransmittable diseases such as $\mathrm{SAH}$, the preventive care is essential to avoid future comorbidity costs caused by $\mathrm{SAH}$, being feasible that this strategy occurs at the level of primary care (Araújo, Ueta, Freitas, 2005; Borges, 2008; Borges et al., 2011; Malachias et al., 2016).

Adding the cost of investing in PC, it was noticeable that the cost of treatment of hypertensive patients increased to US\$ 42,422.70, which was US\$ 407.91 per patient. Although this value is greater than the cost decrease caused by PC in the conventional treatment offered by the PHS, it had an important response in clinical outcome in the short and long term. This is because there was evidence of 
association of the PC program with the reductions in SBP, DBP and TC, showing that the improved clinical results were maintained even after discharge of patients, during which there was no spending on PC.

Thus, comparing the costs and outcomes of the PC and Post PC periods with the baseline, it is noted that there was a cost of US\$ 407.91 and US\$214.96 per patient/year to reduce SBP, DBP and TC of $16.4 \mathrm{mmHg}, 8.7 \mathrm{mmHg}$ and $12.2 \mathrm{mg} / \mathrm{dL}$; and $9.4 \mathrm{mmHg}, 4.6 \mathrm{mmHg}$ and $12.0 \mathrm{mg} /$ $\mathrm{dL}$ in the PC and Post PC periods respectively. Whereas a reduction of $10 \mathrm{mmHg}$ in systolic pressure can reduce by about $25 \%$ the risk of developing CVD (Roush et al., 2014), it can be verified that there has been the cost of US\$ 407.91 and $\$ 214.96$ per patient/year to reduce by $41 \%$ and $23 \%$ cardiovascular risk in the PC and Post PC periods respectively. This analogy to the effectiveness achieved by the PC program can be based on meta-analysis results conducted by Queen Mary University of London, which showed that the reduction of cardiovascular events is associated with reduced blood pressure and not necessarily the use of AH medications in the case of SAH (Law, Morris, Wald, 2009).

It is relevant that in this study the analysis of clinical indicators was performed by repeated measures and that this implied the exclusion of patients for the analysis of certain indicators due to the absence of registration of the same. Thus, a limitation would be not to show improvement of other parameters, which belong to the variables that were with $n$ below the calculated one. However, the main outcome (SBP and DBP) and cardiovascular risk had subgroups with the $n$ contemplated by the sample number. In addition, the costs can be susceptible to the accuracy of the database and the variation of what is committed. However, the main costs were collected from cost spreadsheets of the MHD-RP that remit to the reality of health system. About this study design, we checked the changes in health policies and government programs over the seven years and we did not detect changes that could infer in the results of this study. Although some antihypertensive drugs have been included for distribution in the PHS this fact was not capable of influencing the results of this study because it was not included an innovation drug or a drug to improve the effectiveness of blood pressure control.

It is noteworthy that the profile of hypertensive patients in this study is consistent with the reality of the country, allowing the extrapolation of results for the hypertensive population in the country (Malachias et al., 2016). Above all, it is expected that this work will contribute to the cost of viewing a very prevalent morbidity in the country, SAH, thus assisting in the planning and optimization of health expenditures with this morbidity. In addition, we intend that these results encourage further studies of pharmacoeconomics to assess PC for the care of SAH in Brazil to better support the conclusions and assumptions regarding.

\section{CONCLUSION}

This study was able to formulate hypotheses that there is reduction of the costs when the PC program was implemented, but after discharge of patients in this program, costs increased. However, we can conclude that the value committed promoted the consequence to optimize clinical and healthcare results of hypertensive patients as blood pressure, TC and cardiovascular risk. Additionally, PC program has reduced hypertensive crises, promoting improved patient care in the preventive context verified by the reduction in emergency consultations and an increase in basic consultations. This allowed formulates the hypothesis that PC is able to save health care and economic resources in long-term.

\section{ACKNOWLEDGEMENTS}

We thank the staff of Municipal Health Department of Ribeirão Preto for receptivity to this work and collaboration with data. We thank John Carpenter, from Ribeirão Preto-SP, for translation this manuscript. This work was supported by funding of São Paulo Research Foundation (FAPESP). This organization helped with scholarship for the author Maurilio de Souza Cazarim [grant number 2014/02087-9], URL (http://bvs.fapesp. br/en/pesquisador/673633/maurilio-de-souza-cazarim/). The funders had no role in study design, data collection and analysis, decision to publish, or preparation of the manuscript. Opinions, assumptions and conclusions or recommendations expressed in this article are responsibility of the authors and do not necessarily reflect the viewpoint of FAPESP.

\section{REFERENCES}

Aguwa CN, Ukwe CV, Ekwunife OI. Effect of pharmaceutical care programme on blood pressure and quality of life in a nigerian pharmacy. Pharm World Sci. 2008;30(1):107-10.

Araújo ALA, Ueta JM, Freitas O. Pharmaceutical care as a model technology in primary health care. Rev Ciênc Farm Básica Apl. 2005;26(2):87-92. 
Borges APS, Guidoni CM, Freitas O, Pereira LRL. Economic evaluation of outpatients with type 2 diabetes mellitus assisted by a pharmaceutical care service. Arq Bras Endocrinol Metab. 2011;55(9):689-91.

Borges APS. The clinical impact assessment and economic feasibility of implementing a pharmaceutical care model in a BHU in Ribeirão Preto-SP. [thesis]. São Paulo: Universidade de São Paulo, Faculdade de Ciências Farmacêuticas de Ribeirão Preto; 2008.

Brasil. Banco Central. Indicadores econômicos consolidados. Brasília-DF. 2013. [citado 2016 Jun 15]. Disponível em: http:// www.bcb.gov.br/?INDECO.

Brasil. Ministério da Saúde. Rede Brasileira de Avaliação de Tecnologia em Saúde (REBRATS). Diretrizes metodológicas, estudos de avaliação econômica de tecnologias em saúde. Série A. Normas e Manuais Técnicos. 1 ed. Brasília-DF. 2009. 152 p. [citado 2016 Jun 14]. Disponível em: http://bvsms.saude. gov.br/bvs/publicacoes/avaliacao_economica_tecnologias saude_2009.pdf.

Brasil. Ministério da Saúde. Secretaria de Vigilância em Saúde, Secretaria de Atenção à Saúde. Diretrizes e recomendações para o cuidado integral de doenças crônicas não-transmissíveis: promoção da saúde, vigilância, prevenção e assistência. Brasília: Ministério da Saúde Library [internet]. 2008. 72 p. [citado 2016 Jun 12] Disponível em: http:// http://bvsms.saude.gov.br/bvs/ publicacoes/diretrizes_recomendacoes_cuidado_doencas cronicas.pdf.

Brasil. Ministério da Saúde. Sistema de gerenciamento da tabela de procedimentos, medicamentos e OPM do SUS. 2015a. [citado 2016 Maio 16]. Disponível em: http://sigtap.datasus.gov.br/ tabela-unificada/app/sec/inicio.jsp.

Brasil. Ministério do Trabalho e Emprego. Sistema de informações para acompanhamento das negociações coletivas no Brasil. Encargos sociais no Brasil: conceito, magnitude e reflexos no emprego. 2006. [citado 2016 Jan 20]. Disponível em: http://portal.mte.gov.br/data/files/ FF8080812BA5F4B7012BAB0ABAFF6414/Prod04_2006.pdf.

Brasil. Prefeitura de Ribeirão Preto. Secretaria da saúde de Ribeirão Preto. Prestação de contas de 2013. 2015c. [citado 2016 Jun 20]. Disponível em: http://www.ribeiraopreto.sp.gov. br/ssaude/principal/prestacao/prest-3-quadrimestre-2013.pdf.
Brasil. Prefeitura de Ribeirão Preto. Secretaria de saúde de Ribeirão Preto. Relatório de gestão de 2013. 2015b. [citado 2016 Jun 20]. Disponível em: https://www.ribeiraopreto.sp.gov.br/ ssaude/vigilancia/planeja/2013relatorio_gestao.pdf.

Brasil. Prefeitura de Ribeirão Preto. Secretaria de saúde de Ribeirão Preto. Plano municipal de saúde 2014-2017. 2015e. [citado 2016 Jun 20]. Disponível em: https:/www.ribeiraopreto. sp.gov.br/ssaude/vigilancia/planeja/pms-rp-2014-2017.pdf.

Brasil. Prefeitura de Ribeirão Preto. Secretaria de saúde de Ribeirão Preto. Programas/serviços. 2015f. [citado 2016 Ago 21]. Disponível em: http://www.ribeiraopreto.sp.gov.br/ssaude/ programas/cronico/chd-epidemiologia-desafios.pdf.

Brasil. Prefeitura de Ribeirão Preto. TRANSERP - Empresa de transporte urbano de Ribeirão Preto. Tarifas no transporte público de Ribeirão Preto. 2015d. [citado 2016 Maio 28]. Disponível em: https://www.ribeiraopreto.sp.gov.br/transerp/ i07tarifas-trans.php.

Brazilian Society of Cardiology. BSC. V Brazilian Guidelines for Hypertension (In Portuguese) Brazilian Archives of Cardiology, 2007;89(3):1-56.

Cazarim MS, Freitas O, Penaforte TR, Achcar A, Pereira LRL. Impact assessment of pharmaceutical care in the management of hypertension and coronary risk factors after discharge. PloS One. 2016;11(6):e0155204.

Cipolle RJ, Strand LM, Morley PC. Pharmaceutical Care Practice. 1st ed. New York: McGraw-Hill; 1998. 359 p.

Cipullo JP, Martin JFV, Ciorlia LAS, Godoy MRP, Cação JC, Loureiro AAC, et al. Hypertension prevalence and risk factors in a Brazilian urban population. Arq Bras Cardiol. 2010;94(4):51926.

De-Castro MS, Correr CJ. Pharmaceutical care in community pharmacies: practice and research in Brazil. Ann Pharmacother. 2007;41(9):1486-93.

Dib MW, Riera R, Ferraz MB. Estimated annual cost of arterial hypertension treatment in Brazil. Pan Am J Public Health. 2010;27(2):125-31.

Instituto Brasileiro de Geografia e Estatística. IBGE. Estatísticas do município de Ribeirão Preto-SP. 2013. [citado 2016 Jun 20]. Disponível em: http://cidades.ibge.gov.br/xtras/perfil. php?codmun=354340. 
Ivama AM, Noblat L, Castro MS, Jaramillo NM, Rech N. Consenso brasileiro de atenção farmacêutica: proposta. Brasília, DF: Organização Pan-Americana da Saúde; 2002. 24 p.

Jardim PCBV, Gondim MRP, Monego ET, Moreira HG, Vitorino PVO, Souza WKSB, Scala LCN. Hipertensão arterial e alguns fatores de risco em uma capital brasileira. Arq Bras Cardiol. 2007;88(4):452-7.

Jellinger PS, Smith DA, Mehta AE, Ganda O, Handelsman Y, Rodbard HW, et al. AACE - American Association of Clinical Endocrinologists. American Association of Clinical Endocrinologists' guidelines for management of dyslipidemia and prevention of atherosclerosis. Endocr Pract. 2012; 18(Suppl 1):1-78.

Law MR, Morris JK, Wald NJ. Use of blood pressure lowering drugs in the prevention of cardiovascular disease: meta-analysis of 147 randomised trials in the context of expectations from prospective epidemiological studies. BMJ. 2009;338:b1665.

Lyra-Jr DP, Marcellini PS, Pelá IR. Effect of pharmaceutical care intervention on blood pressure of elderly outpatients with hypertension. Braz J Pharm Sci. 2008;44(3):451-457.

Machado M, Bajcar J, Guzzo GC, Einarson TR. Sensitivity of patient outcomes to pharmacist interventions. Part II: Systematic review and meta-analysis in hypertension management. Ann Pharmacother. 2007;41(11):1170-81.

Malachias MVB, Souza WKSB, Plavnik FL, Rodrigues CIS, Brandão AA, Neves MFT, et al. Brazilian Society of Cardiology. VII Brazilian Guidelines on Hypertension. Arq Bras Cardiol. 2016;107(3 Suppl 3):1-83.

Pagano M, Gauvreau M. Princípios de Bioestatística. 2 ed. São Paulo: Cengage Learning; 2012. 506 p.

Pereira LRL, Freitas O. The evolution of pharmaceutical care and the prospect for the Brazil. Braz J Pharm Sci. 2008;44(4):601-12.
Pontes-Neto OM, Silva GS, Feitosa MR, de Figueiredo NL, Fiorot JA Jr, Rocha TN, et al. Stroke awareness in Brazil: alarming results in a community-based study. Stroke. 2008;39(2):292-6.

Rascati KL. Introdução à Farmacoeconomia. 1 ed. Porto AlegreRS: Artmed; 2010. 278 p.

Rosário TM, Scala LCN, França GVA, Pereira MRG, Jardim PCBV. Prevalência, controle e tratamento da hipertensão arterial sistêmica em Nobres - MT. Arq Bras Cardiol. 2009;93(6):672-8.

Roush G, Fagard R, Salles G, Pierdomenico SD, Reboldi G, Verdecchia $\mathrm{P}$, et al. Prognostic impact of clinic, daytime, and nighttime systolic blood pressure in 9 cohorts of 13,843 patients with hypertension: systematic review and meta-analysis. J Am Soc Hypertens. 2014;8(4):45-64.

World Health Organization. WHO. Cardiovascular diseases (CVDs). Media Centre: Fact feets; 2013.

World Health Organization. WHO. Cuidados inovadores para as condições crônicas: componentes estruturais de ação: relatório mundial. Brasília: OMS Library; 2003. 105 p.

World Health Organization. WHO. Global health observatory data repository. Cardiovascular diseases, deaths per 100.000. Geneva: WHO Library; 2014b.

World Health Organization. WHO. Global status report on noncommunicable diseases 2014. Geneva: WHO Library; 2014a. 282 p.

World Health Organization. WHO. Global status report on noncommunicable diseases 2010. Geneva: WHO Library; 2011. 163 p.

Zubioli A, Silva MARCP, Tasca RS, Curi R, Bazotte RB. Pharmaceutical consultation as a tool to improve health outcomes for patients with type 2 diabetes. Braz J Pharm Sci. 2013;49(1):85-94.

Received for publication on $23^{\text {th }}$ November 2016 Accepted for publication on $02^{\text {nd }}$ March 2017 